Bogdan Walczak

Poznań

\title{
Uwagi o transkrypcji Kazań świętokrzyskich
}

Na wstępie muszę przeprosić za niezupełnie adekwatny tytuł mojego wystąpienia: rzecz będzie nie tyle o transkrypcji Kazań świętokrzyskich, ile w ogóle o transkrypcji średniowiecznych zabytków językowych, choć na przykładzie ostatniego wydania Kazañ ${ }^{1}$.

Nie ulega najmniejszej wątpliwości, że rację mają ci, którzy twierdzą i podkreślają to przy każdej okazji - że transkrypcja jest interpretacją. Można stosunkowo latwo wykazać, że już transliteracja jest interpretacją - a jeśli tak, to tym bardziej jest nią transkrypcja. Explicite wykazali to i pięknie wyegzemplifikowali w swoich tekstach pomieszczonych w ostatnim wydaniu Kazań Wacław Twardzik i Tomasz Mika². Ich wysiłek interpretacyjny, zorientowany wyraźnie tekstologicznie, a więc ukierunkowany na wydobycie wszystkich sensów tekstu poprzez odsłonięcie jego budowy składniowej, podporządkowanej wyrafinowanej organizacji retorycznej, przyniósł, w moim przekonaniu, znakomite wyniki. Pewne wątpliwości czy pytania pod adresem autorów transkrypcji można by zgłosić jedynie w tych kwestiach, które bezpośrednio nie dotyczą semantycznosyntaktyczno-retorycznej interpretacji tekstu Kazań świętokrzyskich.

Na przykład można by zapytać: dlaczego - moim zdaniem jak najsłuszniej - przyjmując lekcję csny, csnego, cso, csoż, nics itd., przyjęli jednocześnie lekcję swiadeczstwo, człowieczstwo, wtodyczstwo itd. miast świa-

\footnotetext{
${ }^{1}$ Kazania świętokrzyskie. Nowa edycja...

${ }^{2}$ W. Twardzik, Jak czytać to, czego nie ma w zachowanych strzępach Kazań świętokrzyskich, [w:] Kazania świętokrzyskie. Nowa edycja ..., s. 103-108 i T. Mika, Interpunkcja Kazań świętokrzyskich, [w:] Kazania świętokrzyskie. Nowa edycja ..., s. 59-80. Mika rozpoczyna swój wywód od tezy: „Transkrypcja tak czy inaczej pozostanie interpretacją” (s. 59), a tego, że już transliteracja też jest w istocie interpretacją, najlepiej dowodzi w ostatnim wydaniu Kazań zestawienie ich transliteracyj i słuszna uwaga, że w dotychczasowych wydaniach niektóre partie tekstu Kazań „[...] były różnie transliterowane (i wskutek tego różnie transkrybowane) przez kolejnych wydawców" (Kazania świętokrzyskie. Nowa edycja..., s. 273).
} 
decstwo, czlowiecstwo, włodycstwo itd. W istocie w obu wypadkach mamy tę samą grupę spółgłoskową, etymologicznie $-\check{c} b s-\rangle-\check{c} s-\rangle-c s-\rangle-c-$. Nie widać podstaw, dla których w różnych formach miałaby się tak różnie rozwijać (tzn. reprezentować różne fazy ewolucyjnej zmiany). Pisownia też nie daje podstaw do takiej interpretacji.

Można by dalej zapytać, dlaczego segment tekstu tradycyjnie - i moim zdaniem właściwie - transkrybowany jako gorzkich stez zmienił się w gorskich słez, czyli dlaczego łzy gorzkie zmieniły się w górskie (bo inaczej nie można odczytać i zinterpretować formy gorskich). W istocie chodzi niewątpliwe o łzy gorzkie (górskie są bez sensu), a nowa lekcja spowodowana jest tym, że realnie zachowało się w tym miejscu tylko skich, a jedynie możliwym w tej sytuacji uzupełnieniem musi być gor. Dowodzi to jednak tylko tego, że pierwotne miękkie $r$, w XIII wieku wymawiane już jako $r z$, zostało tutaj zapisane przez $r s$ (jest przecież w Kazaniach i drugi taki zapis trsy 'trzy'), chociaż w zabytku dominuje pisownia niezłożona i zwykle kontynuant miękkiego $r$ zapisywany jest przez $r$.

Można by wreszcie zapytać, dlaczego autor transkrypcji zdecydował się na ingerencję w zapis milosirdim, interpretując formację jako inny typ słowotwórczy: mitosird $<n>y m$, mimo że mitosirdy reprezentuje starszy i lepiej w słowiańskim słowotwórstwie zakorzeniony typ compositów $z$ drugim członem bezsufiksalnym (ukształtowanym w wyniku derywacji paradygmatycznej, polegającej w tym wypadku na wprowadzeniu formy do deklinacji dawnych tematów na -o-), jak w compositach typu dlugonogi (a nie *dtugonożny), dtugoręki (a nie *dtugoręczny), dtugowtosy (a nie *dlugowtosny), jasnooki (a nie *jasnooczny), ktapouchy (a nie *ktapouszny), Krzywousty (a nie *Krzywoustny), Pięknotyta (Kallipygos) (a nie *Pięknotylna) itd. Oczywiście jest też typ z formantem (współformantem) -n- (dwunożny, leworęczny, mitosierny itd.), ale w świetle naszej wiedzy o prasłowiańskim słowotwórstwie jest to typ wtórny i późniejszy. Jednak niezależnie od stopnia produktywności typu słowotwórczego nie ma podstaw do ingerencji autora transkrypcji w sytuacji, gdy zapis bez tej ingerencji jednoznacznie wskazuje na dobrze umotywowaną formę językową.

Pytania dotyczą jednak szczegółów, a skoro transkrypcja jest interpretacją, żadna transkrypcja nie może być i zapewne nigdy nie będzie od takich pytań wolna.

Generalnie natomiast - czemu już raz dałem wyraz ${ }^{3}$ - zarówno na płaszczyźnie transliteracji, jak i na płaszczyźnie transkrypcji interpre-

${ }^{3}$ Zob. B. Walczak, Refleksje nad nowym wydaniem Kazań świętokrzyskich, [w:] Symbolae grammaticae in honorem Boguslai Dunaj, pod red. R. Przybylskiej, J. Kąsa i K. Sikory, Kraków 2010, s. 161-167. 
tacja autorów nowego wydania Kazań wydaje się wnikliwa i trafna. Toteż, generalnie rzecz biorąc, przyjmuję ją bez dyskusji, choć w niektórych (zresztą nielicznych) szczegółach nie zgadza się ona z moimi intuicjami. Jeśli, nie będąc paleografem, czytam, że względy paleograficzne wykluczają lekcją tet(to), to przyjmuję tę konstatację do wiadomości, choć językoznawcy forma tet(to) dobrze się tłumaczy pod względem etymologicznym (jako paralelna wobec znanych z języków wschodniosłowiańskich form typu tot, etot, powstałych na skutek reduplikacji $(t z+t z)$ zaimka wskazującego $* t z-$ a przypomnijmy, że w świetle nowszych badań coraz wyraźniej się rysuje relatywna bliskość zachodu i wschodu Słowiańszczyzny wobec zdecydowanej odrębności południa $^{4}$ ), natomiast proponowane teć(to) jest dla niego strukturalnie niejasne.

Jak zauważyłem na wstępie, w niniejszym wystąpieniu chciałbym nowe wydanie Kazań świętokrzyskich wyzyskać jako okazję do zwrócenia uwagi na jedno z podstawowych zagadnień transkrypcji średniowiecznych zabytków językowych. Poniższe uwagi i pytania formułuję nie ze stanowiska tekstologicznie zorientowanego historyka języka - interpretatora staropolskiego tekstu, dla którego ten tekst (jako taki, sam w sobie) jest właściwym obiektem badania, lecz ze stanowiska dydaktycznie zorientowanego specjalisty z zakresu tradycyjnie rozumianej gramatyki historycznej języka polskiego, dla którego średniowieczny zabytek językowy jest ilustracją procesów ewolucji systemu językowego na wszystkich tego systemu poziomach (w obrębie wszystkich jego podsystemów czy systemów cząstkowych). Stąd jako nauczyciel akademicki - dydaktyk od lat ćwiczenia z gramatyki historycznej języka polskiego prowadzę wyłącznie na tekstach (co innego wykład, który - jeśli kursowy - powinien mieć formę uporządkowanej syntezy).

Kazania świętokrzyskie ze względu na swoją wyjątkową archaiczność ilustrują (nierzadko wyłącznie, tzn. nierzadko czynią to tylko one) takie procesy, zjawiska, kwestie i formy językowej jak:

- unikatowe relikty pierwotnej odmiany zaimków rodzajowych twardotematowych togo, onogo, tomu;

- archaiczny stan w zakresie form imperatiwu: końcówka $-i \mathrm{w}$ formach akcentowanych (w okresie akcentu swobodnego i ruchomego) na końcówce: pojdzi, dowiedzi, końcówka $\varnothing \mathrm{w}$ formach akcentowanych

${ }^{4}$ Zob. choćby B. Walczak, Zróżnicowanie dialektalne leksyki prastowiańskiej (w dru$\mathrm{ku}$ ). Jak wynika z tego studium, w płaszczyźnie leksykalnej najwyraźniejsza granica przebiega między północą a południem Słowiańszczyzny. 
na temacie: wstań, pośpiej się, otbądź (zgodnie z ustaleniami i interpretacją Jana Rozwadowskiego ${ }^{5}$ );

- liczne (w stosunku do objętości tekstu relatywnie najliczniejsze - osiem form wobec trzynastu w wielokrotnie obszerniejszym Psalterzu floriańskim) formy aorystyczno-imperfektalne, w tym dwa niewątpliwie imperfekty biesze i siedziesze, dwa niewątpliwie aorysty poczęcha i pośpieszycha się oraz cztery formy, w których doszło do formalnego spłynięcia aorystu i imperfektum (choć kontekst pozwala je interpretować jako funkcjonalne aorysty) widziech, idziecha, wzdacha i zapłakacha;

- absolutnie unikatowa (użyta pięciokrotnie w Kazaniach i nigdy nigdzie indziej) i do dziś zagadkowa forma imiesłowu czynnego czasu teraźniejszego $r z e k a^{6}$, a także inne archaiczne tak w płaszczyźnie fleksyjnej, jak zwłaszcza składniowej formy imiesłowowe;

- archaizmy syntaktyczne, jak na przykład constructio ad sensum: lud Boży [...] wiciężstwo odzirżeli czy narzędnik sprawcy: krolewica dziewica porodzonego, stowa zmowiona oćcem świętym;

- liczne archaizmy i osobliwości leksykalne w szerokim tego słowa znaczeniu: reliktowe warianty fonetyczne wyrazów (chocieć, cztwarty, jedziny, kiegdy, tegdy), wyjątkowe przykłady asymilacji ( $z$ dręki wro$g_{o w^{7}}$ ), etymologiczne lub przynajmniej stare, słabo na gruncie polskim udokumentowane znaczenia (będace 'przyszłe' dobro, stadto 'stan' grzeszne i btędne) czy wreszcie stricto sensu archaizmy leksykalne (gladać, kaki, kako, wiciężstwo, wrzemię i wrzemienny itd.).

Względy dydaktyczne przemawiają więc za tym, żeby transkrypcja staropolskich zabytków językowych możliwie wiernie - także w warstwie brzmieniowej - odzwierciedlała właściwości oryginału. Tymczasem przy

${ }^{5}$ Zob. J. Rozwadowski, Historyczna fonetyka czyli gtosownia jezyka polskiego, [w:] T. Benni, J. Łoś, K. Nitsch, J. Rozwadowski, H. Ułaszyn, Gramatyka języka polskiego, Kraków 1923, s. 57-206. Zob. też W. Kuraszkiewicz, O rozwoju polskiego akcentu (Wykład publiczny wygtoszony podczas nadania tytutu doktora honoris causa), „Poradnik Językowy", 1986, zesz. 2, s. 84-90.

${ }^{6} \mathrm{O}$ czym świadczy fakt, że wciąż się pojawiają nowe propozycje interpretacyjne, zob. T. Lisowski, Geneza imiestowu reca w Kazaniach świętokrzyskich: trzy modele interpretacji historycznojezykowej, [w:] Amoenitates et lepores philologiae, pod red. R. Laskowskiego i R. Mazurkiewicza, Kraków 2007, s. 175-184 i W. Mańczak, Rzeka 'mówiąc' w Kazaniach świętokrzyskich, ,Język Polski”, LXXXVIII, 2008, zesz. 2, s. 101-104.

${ }^{7} \mathrm{~W}$ referacie wygłoszonym na marcowym sympozjum poświęconym Kazaniom z nową lekcją i interpretacją tego miejsca wystąpit prof. Tadeusz Witczak, którego zdaniem mamy tu do czynienia nie z - wyjątkowym w takiej pozycji - wstawnym $d$ ( $z$ ręki $\rightarrow z d r e ̨-$ $k i$ ), paralelnym do wypadków (jednak stricte wewnątrzwyrazowych) typu zdradzić $\leftarrow z r a-$ $d z i c ́$ ), lecz z regularnym (choć filologicznie nie udokumentowanym) deverbativum * $d r e$ ka od dręczyć (jak męka od męczyć). 
interpretacji zorientowanej tekstologicznie strona brzmieniowa budzi najmniej zainteresowania i poświęca się jej najmniej uwagi. W tym zakresie, jak się wydaje, ustaliła się pewna konwencja transkrypcyjna (u swych początków chyba w jakimś stopniu zdeterminowana ówczesną wiedzą z obszaru fonetyki i fonologii historycznej), która w niezmienionym kształcie trwa do dziś.

Oczywiście istnieją w tym względzie bariery obiektywne w postaci samych założeń transkrypcji, która polega na oddaniu właściwości dawnego tekstu przy użyciu dzisiejszej pisowni, tzn. (co się formułuje explicite) dzisiejszego zasobu znaków graficznych i (co już explicite formułowane nie jest, ale co jest respektowane w praktyce, przynajmniej w nowszych wydaniach uwzględniających transkrypcję) dzisiejszych (tzn. aktualnie obowiązujących) zasad ortograficznych, przede wszystkim zasady historycznej (etymologicznej) i zasady konwencjonalnej (głównie w kwestii pisowni łącznej i rozdzielnej oraz użycia wielkich liter).

Przy takich barierach i ograniczeniach trzeba się pogodzić z tym, że w Kazaniach świętokrzyskich zapisywaną znakiem $\varnothing$ ówczesną jedną samogłoskę nosową o brzmieniu nosowego $a$ (tzn. [a]) w transkrypcji zastępuje się literami $e$ i $a$ zgodnie z dzisiejszą dystrybucją samogłosek nosowych. Choć to oczywiście utrudnia dydaktykę, tak być musi, gdyż innej możliwości w tym względzie nie ma (nie ma możliwości zapisania samogłoski nosowej o barwie ustnej $a$, wymawianej albo wyłącznie, albo przynajmniej w pewnych pozycjach synchronicznie, przy użyciu będącego do naszej dyspozycji zasobu znaków współczesnej polskiej pisowni. Z tych samych względów nie można w transkrypcji Kazań czy innego tekstu średniowiecznego zaznaczyć takich właściwości prozodycznych jak miejsce akcentu, wartość iloczasowa samogłosek itp.). Są jednak właściwości, które mogłyby być oddane w transkrypcji, a - o ile mi wiadomo - nigdy i nigdzie nie są uwzględniane.

W odniesieniu do Kazań taką właściwością jest na przykład twardość pierwotnych grup $k y, g y, k e$, ge czy miękkość (faktyczna, fonetyczna, a nie tylko, jak dziś, funkcjonalna) spółgłosek $\check{s}, \check{z}, \check{c}, z, c^{\prime}, z^{\prime}, r \check{z}, l$, które dziś określamy mianem historycznie lub funkcjonalnie miękkich; ta faktyczna, fonetyczna miękkość skutkowała następstwem po nich samogłoski $i$, a nie $y$. Dzisiaj wiemy ponad wszelką wątpliwość, że grupy $k y, g y$, $k e$, ge przeszły w ki, gi, kie, gie na przełomie XV i XVI wieku - w epoce Kazań panowała zatem jeszcze pierwotna wymowa twarda ${ }^{8}$. Nie ma więc

${ }^{8}$ Wystarczy tu przywołać najnowsze kompendia z zakresu gramatyki historycznej i historii języka polskiego, jak K. Długosz-Kurczabowa, S. Dubisz, Gramatyka historyczna ję- 
żadnych przeciwwskazań, by transkrybować na przykład asyrsky, pogańskego, skoro grupy tego rodzaju istnieją we współczesnej pisowni polskiej (na przykład kynologia, kelner). Zysk dydaktyczny takiej transkrypcji byłby bezsporny. Na przykład nazwa Naket z Bulli gnieźnieńskiej, $\mathrm{z}$ twardym $k e$, wyraźnie by wskazywała na pochodzenie $e$ z jeru twardego, gdy tymczasem transkrypcja Nakiet słabszym studentom sugeruje pochodzenie $e \mathrm{z}$ jeru miękkiego i dopiero dodatkowe naprowadzające pytania uzmysławiają im, że jer miękki musiałby w takiej formie spowodować już pierwszą palatalizację prasłowiańską, której skutkiem musiatoby być $\check{c}$ na miejscu $k$.

Podobnie, choć nie jesteśmy w stanie oddać w transkrypcji miękkiej artykulacji spółgłosek $\check{s}, \check{z}, \check{c}$ itd., można by na nią wskazać przez następujące po nich $i$, a nie $y$. Można by więc transkrybować żidowskego, zsiekszi, pośpieszicha, Bożi, tysięci, na morzi, waszich, towarzistwo, Trojci, grzesznici, cztwioraci itd. Nie ma żadnych przeciwwskazań, by tak transkrybować, skoro wiemy bezspornie, że stwardnienie tego typu spółgłosek też nastąpiło na przełomie XV i XVI wieku (a zdaniem niektórych uczonych na pewnych obszarach polskiego terytorium językowego może nawet trochę później) ${ }^{9}$, a współczesna polska pisownia zna takie połączenia, na przykład circa, cirrus, citroen, czikos, żigolak itd.).

Przyjęcie zasady (w teorii przecież chyba powszechnie i zgodnie przyjmowanej), że wszędzie tam, gdzie to jest możliwe, tzn. w ramach zasobu środków graficznych (znaków) i zasad współczesnej pisowni polskiej, bez wykraczania poza jej granice w kierunku zapisu fonetycznego - wszędzie zatem tam (powtórzmy), gdzie to jest możliwe, oddajemy w transkrypcji możliwie najwierniej autentyczne brzmienie średniowiecznego tekstu, przybliżyłoby znacznie transkrybowane wydania średniowiecznych zabytków językowych do opracowywanych przecież w przeważającej mierze na ich podstawie (gdyż przy użyciu metody filologicznej) naukowych opisów ewolucji systemu językowego polszczyzny. Korzyści takiego przybliżenia (lepszego skorelowania podstawy tekstowej i podręcznikowego opisu) byłyby bezsporne i wielorakie.

zyka polskiego. Podręcznik dla studentów polonistyki, Warszawa 1998 czy B. Walczak, Zarys dziejów języka polskiego, wyd. II poprawione, Wrocław 1999.

${ }^{9}$ Zob. przypis 8 . 


\section{Summary \\ Some Remarks on the Transcription of the Holy Cross Sermons}

Bogdan Walczak discusses on the instance of the Holy Cross Sermons issues related to the transcribing of texts in medieval Polish. Convinced that all transcriptions are in fact interpretations, the author presents examples of editorial interferences into text of the Holy Cross Sermons which in his opinion have changed the meaning of the original. He nevertheless emphasizes that the interpretation to be found in the new edition is very thorough and correct. 